\title{
MONITORING AND EVALUATION OF THE ADOPTED STRATEGICS DOCUMENTS IN SERBIA
}

\begin{abstract}
This paper examines the application of strategic planning in Serbia. The research focus is on the definition of strategic goals and on the selection of strategic priorities. In order to meet goals, each strategy defines appropriate action plans for its implementation. Action plans thoroughly define activities, measures and projects, activity-bearers, implementation deadlines, success indicators, funds, financing sources, legal and institutional framework. Paper investigates the current practice of strategic documents implementation. Further, issues with monitoring, reporting and evaluation are examined. Finally, recommendations have been made for more transparent and efficient management, aiming to improve the allocation of budgetary and non-budgetary funds.
\end{abstract}

Keywords: strategic planning, strategic management, public policies, efficient management

* Business and Law Faculty, University MB, Belgrade, Serbia; stamatovicm@sbb.rs

** PBusiness and Law Faculty, University MB, Belgrade, Serbia; galena.mcl@gmail.com

*** University Union; Belgrade, Serbia; ljubisastamatovic@gmail.com 


\section{Introduction}

In modern public sector management, strategic planning has become the synonym for structured and integrated approach to public policy, based on facts, analysis and consensus. It is launched to fulfill and implement broader policy goals, or to react to the complexity of a problem. Establishing multiyear developing guidelines in the public sector context includes the definition of desired goals and means of their fulfillment. ${ }^{1}$ Strategic planning of the local self-governments' sustainable development has been an indispensable management segment in Serbia since 2000 . When it comes to legal regulation, strategies are connected by several laws: The Law on the Budget System, ${ }^{2}$ The Local Government Law, ${ }^{3}$ The Regional Development Law. ${ }^{4}$ Most of strategies adopted in local governments in Serbia are technically written analyses of economic, developing, legal and institutional advantages, or obstacles that need to be overcome in developing strategic goals for advancing developing potential of the municipality.

Methodologies include all principles of quality strategic planning in defined time frame and according to desired standards. However, there are no precise data how far and to which extent they have been practically applied. Most of defined strategic goals haven't been synchronized on either vertical or horizontal level. Problems often overlap, the lack of two-way cooperation between the institutions has been noticed; there is no precisely defined executive body, that is, public enterprise or institution in charge of strategic goals implementation. In defining priorities, there is a problem of synchronizing priorities between republic strategies and local project priorities. There are many goals that are unattainable, or they are not attainable in defined time limit. ${ }^{5}$ There are no clearly defined mechanisms for participatory approach, that is, the participation of all concerned parties, in strategies creation as well as in their implementation as a form of control tool of local authorities. In strategies, there are no developed indicators for monitoring the strategies implementation fulfillment, which should help the decision makers to find out about what has been achieved, about faced problems, which priority areas have been meeting the planned goals and what benefits the citizens have had from municipal projects.

Rabrenović, M.(2011) „Strategic management in public sector“, Official Gazette of the Republic of Serbia, Belgrade, pp. 45.

2 Official Gazette of the Republic of Serbia, The Law on the Budget System [on Serbian], 54/2009, 73/2010, 101/2011, 93/2012, 62/2013, 63/2013, 108/2013, 142/2014, 68/2015, $103 / 2015,99 / 2016,113 / 2017,95 / 2018,31 / 2019$ i $72 / 2019)$

3 Official Gazette of the Republic of Serbia, The Law of State Government, 79/2005, 101/2007, 47/2018, 30/2018.

4 Official Gazette of the Republic of Serbia, The Law of Regional Development, no. 51/2009, 30/2010, 89/2015.

5 Pavlović-Križanić, T.(2010) „Handbook of Strategic Planning and Local Development Management, Center for Regionalism and Friedrich Ebert Stiftung, pp. 30-36. 
The research subject of this paper is focused on defining the implementation process and control of strategic documents implementation. In accordance to this, the aim of the paper is to underline that monitoring and evaluation are not an additional administrative burden but a useful managing tool which can help local self-governments to use public resources in a more transparent and responsible way, in order to create benefits for the community as well as to generate new ideas for future activities. Dealing with these issues is systematic in its nature and it takes development of the way of managing the strategies creation which will define different roles and responsibilities of all participants. Also, management and monitoring require constant update and evaluation according to the extent of realization and results fulfillment.

\section{The concept and key stages of strategic planning}

The main goal of strategic planning is to clearly establish goals, priorities and strategies, and define measures for evaluating the success in defined goals fulfillment. The mere existence of strategic plans in Serbia doesn't mean that there is systematic management and operation. Development strategy is a process of integrated planning regarding all common issues (social inclusion, IT society, environment etc.). As an overarching strategy, it should define guidelines, goals and measures relevant to all sectors, thus participating in creation of favorable conditions for all other undertaken plans at the municipality/city level. ${ }^{6}$ Lately, there has been some serious systematic work on establishing planning process and procedures, local strategies preparation and creation, integrated planning importance and synchronizing the strategic plans and activities and action plans with preparation process and budget execution, the project cycle establishment, as well as monitoring process establishment and attained result report. Long-term development strategy, that is, Strategy for Local Sustainable Development recognizes three main sectors: economic, social and environmental protection sector. Within the Strategy, sector plans are made for each of the three sectors, and often there are further divisions within each of the sectors. The planning and creation process of the development strategy is initiated by local self-government.

Its implementation is based on bottom up principle, which implies definition of priorities through consultative processes of all levels of authority and all sectors of the society. It is considered that there are three groups of municipalities in Serbia:

- The municipalities that have a comprehensive developing local community plan.

Stamatović, M., Maksimović, S., Sućeska, A.(2020) „Risk Management as a part of the Internal System of financial controls-practice in the public sector of Serbia“Panevropski univerzitet Apeiron, Fakultet poslovne ekonomije, Economy and MarketCommunication Review - EMC Review,Vol. X, No 2.

Vol. 18, № 1, 2021: 1-22 
- The municipalities that have only sector plans (in areas estimated by the municipalities themselves to be the most important for development, or those are the municipalities that had provided external financing).

- The municipalities with no sector plans.

The strategic plans quality depends on the way the planning process itself is organized, to what extent specific needs of every community have been defined, to what extent the real estimation regarding available funds and human potentials has been effected, and it also depends on the number of the participants in the process (the employed as well as all other concerned parties).The strategic document includes the current overview, the description of the main problem but also of the advantages, SWOT analysis, defined strategic goals and priorities, and it's most important part is the action plan, that is, the list of project ideas. Thus defined plan is the basis for sector action plans creation and the source of ideas for project registration at numerous domestic and foreign funds.

In the implementation process there is often no impression that the chosen priorities are underlined in strategies when, for example, we want to apply for some projects, for which external funds for financing and co-financing are provided. In this sense the comprehensive approach is not realized, and not all environment factors are taken in consideration, such as demographic trends, microeconomic situation, political trends or social movements. Instead, certain segments are chosen to be developed according to the given model. ${ }^{7}$ Methodologies for integrated planning of the local self-governments' development should help facilitating and equalizing planning practice, responsible and proactive development management in accordance with the existing legal frames which define development planning on the local level. The main principles of Development Strategies creation:

- The local self-governments' units govern the process of strategies creation.

- They are responsible for the creation process as in this way they strengthen institutional and technical capacities, with the aim of efficient plans implementation and increase of absorptive capacities of a municipality/ town.

- The strategy creation approach is participatory, as it includes all concerned parties.

- The process is divided into five stages repeated over 10-year-cycles, while the management and evaluation require constant updating according to the extent of realization and achieved results (Table 1.).

Bataljević, D., Jerotijević, D., Logarušić, D.(2016) „Uporedna analiza Najpoznatijih modela lokalne samouprave“, Ekonomika, Niš, Vol.62, pp.141-154. 
Table 1: Five main stages of Strategic development creation process

\begin{tabular}{|l|l|}
\hline STAGES & DOCUMENTS \\
\hline 0. The initiation of the strategic planning process & $\begin{array}{l}\text { Organization structures - } \\
\text { regulations }\end{array}$ \\
\hline 1. The current state analysis - community profiling & Sustainability reports \\
\hline 2. Priorities, prospects and goals defining. & Strategic documents \\
\hline 3. Projects and activities for defined results & Action plan \\
\hline 4. Implementation, management, monitoring & Managing system \\
\hline 5. Marketing and communication & Marketing and communication plan \\
\hline
\end{tabular}

Integrated approach starts with the hypothesis of inter-dependence between natural, social and economic aspects of a community and has to contain time dimension (long, medium or short term). It is important to emphasize that integrated approach implies that every sector and every level contain their main focuses, and that in interaction they should achieve a synergetic effect in the form of sustainable and fair development for the entire community.

The participation in planning local development implies taking active part of all concerned parties (citizens, civil society, private sector and marginal groups) in all stages of local development management, in both planning and plans realization. Standardization assumes defined form of planning for all local self-governments. In this respect, standardized methodology includes strategic, tactical and operative level of planning, which synchronizes long, medium and short term. ${ }^{8}$ Such a strategy is a unique systematic document and not a mechanical sum of plans. For municipal authorities the strategy is a basic instrument for development management, which helps it to balance conflicted requirements for results achievements in short and long term. The first planning level is strategic platform with a prospect and goals of the community long term development. Strategic platform comprises a period of ten years. The second level is the elaboration of the strategic platform through appropriate plans of economic and social development and environment improvement with high degree of their synchronization. ${ }^{9}$ The time frame of sector plans is five years. The third operative level involves operationalization of the strategic platform and sector plans through elaboration of financing and execution models, including the preparation of organizational and human capacities.

8 Maksimović, S., Lunjić, A., Parojčić, D.(2020) „Financial management and control - A New Management Concept in the Context of the Serbian Public Sector“, Megatrend revija, Vol.18. No.2.

9 Efimov, Lj.,Trpeski, P., Gockov, G.(2016) „A comparative analysis of the most popular models of local government", Ekonomika, Niš, Vol 62. pp.29-48. 


\section{Strategy implementation - what have we achieved?}

For the success of a strategy, it is not only necessary for it to be well formulated, but the conditions should also be created for its consequent implementation. Although it is logical that the strategy should be formulated first, and then executed, it is still very useful to realize, at the moment of its formulation, the extent and type of changes which its implementation will require. While in strategy formulation the enterprising ingenuity and vision of the strategy coordinator come forward, in implementation the skill and talent to do the work in the right way is of crucial importance. For strategy definition extrovert orientation and external factors are often more important, while for the implementation what is predominantly important is internal organization which will enable the realization of desired performances through motivation, communication, coordination and control of the executors' activities. ${ }^{10}$ There are also some dangers for the strategy success in the domain of strategy formulation and implementation, which is shown in the table 2 .

Table 2: Diagnosing of strategic problems

\begin{tabular}{|l|c|c|c|}
\cline { 3 - 4 } \multicolumn{2}{c|}{} & \multicolumn{2}{c|}{ Strategy formulation } \\
\cline { 3 - 4 } Strategy implementation & Good & Good & Bad \\
\cline { 2 - 4 } & Bad & Sifficulties & Roulette \\
\hline
\end{tabular}

For the strategy success it is necessary to acknowledge external and internal challenges and limitations, as well as to create organizational, motivational, resource and other possibilities for its implementation. The roulette situation is characterized by badly formulated strategy which can be corrected through its implementation. This means that during the implementation the difficulties are pointed at and the change of the strategy is initiated. Similar difficulties also can arise when the strategy is well formulated but poorly implemented. ${ }^{11}$

In such cases there is often unjustified opting for strategy change, instead of systematic removal of obstacles for its implementation. Finally, the failure is inevitable when the strategy is poorly formulated and equally poorly implemented, so there is confusion about the right failure diagnosis and the order of the actions. Depending on the extent of changes that are needed to be done, the scope and the nature of efforts which are needed in the implementation strategy will also differ. Of course, we talk about the changes which are in the function of the goals and strategic priorities fulfillment and they have operative and long

10 Serbia-Local Government Reform Program-SLGRP(2002) „Model of strategic plan of municipality“, Belgrade.

11 United States Agency for International Development -USAID (2008) „The Guide of strategic planning for towns and municipalities“, Belgrade. 
term dimension. ${ }^{12}$ When there are only minor problems, and there is no pressure for their quick solution (implementation horizon is long enough), the implementation strategy will include evolutional intervention, that is, incremental changes.

If there are small changes in short terms, they are made by direct reaction of the strategy executors to the critical points (managing intervention). If there are changes which cannot tolerate delays, we are talking about complex intervention, when the strategy coordinator has to include all concerned parties and to synchronize activities with changes report. ${ }^{13}$ And, when there are major long term changes, it is necessary for them to be made in stages (sequential intervention). Each of the given approaches has its good and bad sides, so the strategy coordinator has a task to clarify and operationalize the solutions through communication and coordination processes, and to adapt the implementation system with anticipation of possible obstacles which can appear on the way of successful implementation. ${ }^{14}$ For efficient implementation processes management apart from organization structure, resources allocation and relevant procedures creation designing, it is also necessary to make a selection of people for key responsibilities, and establish appropriate IT system. Implementation predominantly depends on the people, so the most important precondition is the skill of strategy coordinator to ensure propulsive realization of the defined strategy through communication and coordination processes.

The final phase of strategic management process is control and revision of the strategy. The planning and the control are processes which are closely connected and there is no point in planning if these processes cannot be controlled. Also, the control is not valid if there was no planning before it. These are two processes which stimulate and enrich one another.

Control activities are based on legal regulations, rules and internal procedures which thoroughly arrange control activities. ${ }^{15}$ Institutions arrange control procedures, authorizations and responsibilities primarily according to the current legal regulations, and internal acts. Internal acts are needed to arrange strategic planning processes, processes of the budgetary bookkeeping, public procurement processes and procurement where law is not applied, contracting, record of business events and transactions, assets (tangible and intangible), payment of own

12 Hilb,M.(2008) „New Corporate Governance:from good guidelines to great practice",Corporate Governance: An International Review, Vol.13,pp.569-589.

13 Hinna A., Scarozza, D., Rotundi, F. (2018) „Implementing risk management in the Italian public sector: Hybridization between old and new practices",International Journal of Public Administration, 41(2), pp. 110-128.

14 Municipal Improvement and Revival Programme MIR2 (2008) „Strategic planning and implementation, $2^{\text {nd }}$ phase, Jablanica and Pcinja District”, Leskovac.

15 Maksimović, S., Stamatović, M. (2018) „Risk management as a part of management public investment projects", $4^{\text {th }}$ - International Scientific Conference International Scientific Conference- Innovation as an initiator of the development,Faculty of Applied Management, Economics and Finance, Belgrade. 
revenues, refund of the non-earmarked funds or budgetary funds which are left at the end of a budgetary year. Considering the fact that implementation of the given processes takes a large number of organizational units, it is very important that the rules and procedures, participants' responsibilities and authorizations, control procedures and prescribed forms and patterns are clearly established. ${ }^{16}$

Strategies implementation in Serbia has not shown adequate and expected results, because thus conceived development management requires the existence of a certain legal, institutional and methodological frame as well as administrative capacity which will ensure efficient realization of developing policies in all domains affecting the sustainable development and citizens' quality of life, and which have been defined in adopted strategic documents. ${ }^{17}$ Regarding the fulfillment there are no precise data on how far and to what extent the implementation of strategic documents has been done in practical terms.

The focus of the analysis of this paper was on the employees of local economic development offices, non-heads of finance departments in local self-governments in Serbia and directors of public companies that should monitor all activities in their organization, as well as whether the control activities are functioning properly; whether the control environment appropriate, whether the risks and opportunities have been adequately addressed, all with a view to achieving the set goals in the strategic documents as well as in the operational plans. During the last decade of strategic planning practice in Serbia, it can be observed that the realization of public policies remains at the level of promise, so management practices using goals in addition to control and monitoring function are aimed at strengthening strategic policy and preserving integrative processes, and the holistic approach of strategic management will be analyzed in the paper. through the creation of a new framework for establishing best practice in the field.

In accordance with the identified problem and the subject of the research, the basic hypothesis of the research is:

- Exclusively set system for monitoring and evaluation of adopted strategic documents is an effective mechanism for defining feedback, comparing results with set goals, determining size and significance of deviations and taking appropriate actions using all available resources in effective and efficient manner that accomplish the goals.

Specific hypotheses:

- The planned objectives in the strategic documents are the basis of monitoring and evaluation.

16 Ministry of Finance of the Republic of Serbia (2019),,The manual for financial management and control", Belgrade.

17 Maksimovic, S.(2016), Relatonship between strategic planning and program budgeting in the function of efficient management of public policies”, Doctoral dissertation, „UnionNikola Tesla" University, Faculty of Business and Industrial Management, Belgrade. 
The monitoring and evaluation system must be explicit and codified. Also, unambiguous principles must be used in building a monitoring system.

Monitoring and evaluation are very important steps in the public policy cycle and are part of the „learning” phase of public policy, in which it is necessary to monitor the implementation of a given public policy. ${ }^{18}$ It is for this reason that attention in this work is focused on assessing the current state of the achievement of the set goals and progress in implementing the results defined in the existing strategic documents. The research conducted at the Belgrade Institute of Economics and Law during September 2019 and February 2020 included an analysis of the capacities of local governments in Serbia in the field of established monitoring system, i.e. monitoring the implementation of adopted strategic documents. The results of the analysis are based on the responses of employees in the Local Economic Development Offices and heads of financial services from 79 municipalities (52.7\%), who sent a questionnaire response from 120 municipalities to which the questionnaire was sent. In a group of 32 public companies founded by the Republic of Serbia, 20 companies were analyzed through interviews with company directors who participated during the two lecture cycles. Secondary data available on public company websites were also used.

According to the last mapping of the strategic plans done every year byStanding Conference of Towns and Municipalities (SCTM), in Serbia there are 897 registered planning processes in municipalities, as well as 488 adopted valid plans. ${ }^{19}$ The conducted analysis suggests that the strategies of sustainable development exist in all surveyed municipalities. General urban plan (in 49 surveyed municipalities), Spatial plan (in 13 surveyed municipalities), Action plan for local economic development (in 5 municipalities), Detailed zoning plans (only in one of surveyed municipalities), Plan for capital investment in two surveyed municipalities.

Through our research we found that with the methodological frame used for local strategy creation 72 subjects (91.1\%) were familiar with it, while 7 (8.9\%) of them said they were not familiar with it. All strategies are multiyear - mostly with time range of 5-10 years, and in some, the year of the document termination is not defined. Most of the strategies were prepared by small number of experts, without the participatory approach, and they mostly don't define mechanisms for efficient application, or the principles of responsibilities and authorization distribution in implementation and monitoring of defined goals.

\footnotetext{
18 Jang, O.,Kvin, L. (2003) „Writing Effective Practical Policy Proposals: A Guide for Practical Adviser politics in

Central and Eastern European countries", Open Society Institute, Belgrade.

19 Standing Conference of Towns and Municipalities-SCTM (2015), Analysis of strategic planning and program

budgeting on the level of local self-governments, Belgrade.
} 
Although still in evolution, the Sustainable Development Strategy still proves to be a useful tool in local development management. Namely, most of the subjects think it affects the formalization of the planning process which develops tools for managing development process, that is, $77.2 \%$, while $11.4 \%$ think it strongly affects the process and there are $11.4 \%$ of those who agree with this statement. The answers are thus encouraging, but the level of their knowledge is not on the highest level $-86 \%$ believe they have average knowledge on the planning process so this requires further improvement. When it comes to the statement Developing strategy broadens perspectives and suggests codependence between developing activities as well as the need for coordination of developing agents $69.6 \%$ of the subjects think the strategy does this to a significant extent $12.7 \%$ think the strategy does this to a very significant extent and $17.7 \%$ think the strategy does this on an average level. Their knowledge correlates to their attitudes. Regarding the statement the Strategy enables regular control and monitoring of developing activities, $51.9 \%$ think the strategy does this to a significant extent, $12.7 \%$ think it does this to a very significant extent, $35.4 \%$ think it does this on an average level but their knowledge does not correlate do the attitude, considering the fact that the subjects think they have average level of knowledge on the given statement of $87.3 \%$.

In most of strategic documents there is no clearly defined organ in charge of strategic goals implementation, or clearly arranged net of coordination between local and republic authorities' institutions in charge of their implementation in order to improve the development of local self-government units.

\section{The monitoring of strategic documents based on the results}

The monitoring of the strategy is crucially important for the result management and implementation and it consists of constant collecting of data on certain programs and projects realization within the strategy. ${ }^{20} \mathrm{On}$ the strategy level the strategy coordinator receives a report on progress measurement and trends which he has to analyze based on already known activity plan. Monitoring provides the decision makers with the opportunity to constantly monitor feedback on programs and projects monitoring and we can ask a question -how often and how detailed reports are expected? Regarding this, strategy coordinator needs to make appropriate decisions in order to identify actual and possible success as well as problems soon enough so as to react in due time. ${ }^{21}$ Sometimes reports are too extensive to be useful while others are too general and thus equally

20 Standing Conference of Towns and Municipalities-SCTM (2012) „Monitoring and evaluation of strategies of local sustainable development”, Belgrade.

21 Parashkevova, E. (2020) „Integrating Project Risk into Risk Management Strategies in Public Sector Organizations", International E-Journal of Advancesin Social Sciences 6 (16), pp. 283-293. 
irrelevant. Although, too frequent reports can take too much of coordinator's time, and too long intervals between the reports can make it difficult to spot the problems timely. For this reasons, it is necessary at the very beginning to decide which data and in which form are necessary regarding standard formats for information delivery.

The monitoring (RBM) of public policy is a continuous process of gathering and analyzing information in the flow of a strategic document, with a focus on the results / outcomes of public policy performance, in order to compare the quality of implementation of a given policy against the set goals. ${ }^{22} \mathrm{RBM}$ is a powerful management tool that helps state institutions show impact and outcomes to their stakeholders and target groups. It is similar to a process (implementation) monitoring system, but reaches further in its focus - results-based monitoring does not end at implementation, i.e. with inputs, activities and outputs, is already predominantly focused on outcomes and impacts.

Defining results is critical to a results-based monitoring system (RBM). The construction of this system is deductive to the process by which inputs, activities and outputs are derived from defined outputs. The baseline and target value indicators are key elements of a performance monitoring framework in the implementation of public policies adopted by specific strategic documents. The preparation of the monitoring process requires a detailed analysis of the situation / problem to determine the long- and medium-term goals, as well as specific measurable results (SMART). Indicators for their monitoring are defined on the basis of precisely defined goals and results. Quality definition of goals and results in the strategy document, at all levels, is a good basis for determining quality indicators, and thus for successful monitoring and evaluation of the adopted strategic document.

Determining the results involves understanding the hierarchy of results and the resulting hierarchy of indicators. There needs to be a logical correlation between long-term (impact), medium-term (outcomes) and short-term (output) results. ${ }^{23}$ In the RBM approach, there are different levels of outcome and output determination. Sometimes they are difficult to distinguish, but in essence the definition of the resultant level depends on the level of document aggregation, for which a logical framework matrix is developed. It is important that results be defined at the level of what one wants to achieve, so that change in the reality that we want to act can be seen. ${ }^{24}$

22 Kusek,J. Rist,R.(2004) „A Handbook for Development Practitioners:Ten Steps to a ResultsBased Monitoring and Evaluation System”, The World Bank, Washington.

23 Žarković-Rakić, J., Aleksić-Mirić, A., Marić S., Miletić. J., Lazarević. M. (2012) „Handbook for Monitoring and Evaluation of Public Administration Reform Policy”, Foundation for the Development of Economic Science, Belgrade.

24 John, P.(2002) "Quantitative research in Theory an Methods in Political Science", DejvidMarš, Geri Stoker, Palgrave, New York, USA. 
Based on the monitoring of progress in reaching the identified target values of the indicators, the degree of achievement of the defined goals is monitored. The evaluation of the strategy is the process of the periodical evaluation of its: relevance, output, effect and efficiency based on predefined strategic and operative goals. Evaluation estimates the content of certain projects and activities by which the whole plan is realized and conclusions are made about the success of their realization. It is necessary to make a difference between the monitoring indicators and the evaluation indicators. ${ }^{25}$

Monitoring indicators provide the information on the way resources are used, level to which the planned goals are met, the amounts of sustenance, number of users etc. The three main elements of efficient monitoring are:

- The output measuring frame (indicators).

- The reporting mechanisms.

- An independent and objective group of concerned group representatives (workgroups) which is enabled to have insight in reports and to recommend initiative for intervention based on an objective estimation.

The monitoring practice is a standard characteristic of goal-oriented management and is a mechanism which ensures objective monitoring and constant review of the programs and projects implementation. On the local level, it is systematic and regular monitoring of the progress in implementation of the strategy and action plan realized in monitored period. The monitoring does not just follow the strategy implementation but also looks at way of priority projects preparation and their implementation and realization regarding the plan. Within these processes the data are collected about the achievements and spent resources, based on which it is measured to which extent the beforehand defined goals have been fulfilled. ${ }^{26}$

The evaluation is directed to the analysis of the support system effectiveness and provides the information on support measures effects, and information on reaching the strategic goals, that is, the goals of each and every measure. ${ }^{27}$ The aspects of evaluation are: the relevance evaluation (compatibility between the effects and actual needs) and the sustainability evaluation (the expectations connected to long term and effect of certain measures). The evaluation primarily pertains to 'intervention logics' and helps answer the questions such as:

- Which change has been made?

- What has functioned and why?

$25 \quad$ European Commission (2006) Indicators for Monitoring and Evaluation: An indicative methodology, The New Programmimg period 2000-2006, Working Paper 3, Brussels.

26 Standing Conference of Towns and Municipalities -SCTM (2012) „Monitoring and evaluation of strategies of localsustainable development", Belgrade.

27 Cvijović, M.(2014),Strategic planning and management on the local level in Serbia”, Chamber of Commerce and Industry of Serbia. 
- What has not functioned and why?

- What could have been done differently?

- Which adjustments and changes are necessary for the next time?

The evaluation discusses the crucial issues of the policy cycle, connected to the public sector.It gives answers whether the implemented policy is in accordance with the planned general and specific goals, whether these goals are relevant for the established needs, and whether they require intervention in the context of market economy - that is, whether the intervention would be the only way to solve the problem. ${ }^{28}$ In this respect, the evaluation discusses:

1. Relevance - to what extent the intervention goals solve the identified problems, and whether the programs contribute to the overarching political goals and $\mathrm{EU}$ accession processes.

2. Efficiency-defines the relation between the intervention expenses and what is achieved by it.

3. Efficiency - defines to what extent the program has contributed to the planned goals, expressed through global and operative goals.

4. Usefulness - establishes whether the undertaken intervention has made some changes for target groups of users compared to their initial needs.

5. Sustainability - monitors whether the intervention effects will last after its termination - whether the intervention will provide long term benefits.

The basic set of tools for evaluation is indicators definition, which should be done in advance, that is, at the beginning of implementation and in this respect there are four main levels of indicators:

- The input or resource indicators-they measure the needed input. Financial indicators are main markers because they answer whether the program is faced with the budgetary exceeding risk, running late or lack of spending.

- The output indicators-have to do with activities - the number of small enterprises, the duration of irrigation system setting etc.

- The result indicators - enable measuring immediate and direct intervention effects (the information on capacity change, the increase in social protection users, increase of basic enterprises etc.)

- The effect indicators- pertain to the consequences which are not connected to the immediate effects on direct users. They may have specific influences referring to the effects which happen during a certain interval of time and are directly connected to the activity and long term global effects which affect general population. The effect indicators definition is the most demanding aspect of the evaluation.

28 European Commission (2006),Common Indicators for Monitoring Rural Development Programming 2000-2006”, Commission working document d/761 Final, Brussels.

Vol. 18, № 1, 2021: 1-22 
The baseline of the indicator is data, qualitative or quantitative, on the initial status of the indicator (the first important measures of the indicator) at the beginning of the monitoring or before the monitoring itself, with which the information obtained by monitoring the indicator is compared and in relation to the progress in the implementation of a given strategic document. ${ }^{29}$

The target value represents the desired level of performance that will be achieved over a period of time and which is defined after the baseline of the indicator and the sum of that value with the desired performance enhancement. Goal value is generally presented as a periodic value (eg annual or biennial), that is, progress in achieving a goal over a period of time. ${ }^{30}$

Monitoring and evaluation frame. The development/action plan requires a certain organization structure which usually consists of monitoring committee as an operative body for implementation. ${ }^{31}$ The committee has appropriate legitimacy which means that it is appointed by the municipal assembly, or the body that is equal to it, such as the town council. The committee members should be:

- Members of some sector workgroups (like representatives of some educational institutions etc.)

- Representatives of public enterprises who will physically implement certain projects or part of projects.

Monitoring committee relies on the data base created in action plan. This should be a document which is a list of activities in Excel with additional columns which indicate progress compared to the deadlines set in action plans, and above all it is a set of basic indicators which will give the report basis to the monitoring committee. ${ }^{32}$ The information provided by the monitoring committee is about the following issues:

- Whether certain activity will finish in the given time frame according to the action plan.

- Whether there is a change for certain activities (the type and reasons for the change should be given).

- Whether certain activity is cancelled or postponed (reasons).

$29 \quad$ Krivins,M.(2014) „Ideas for operationalizing the monitoring, reporting and evaluation (MRE) systems in the Reform StrategyPublic Administration (PAR) and the Action Plan for its Implementation in the Republic of Serbia", SIGMA, Belgrade.

30 Improvement of Performance -Based Management -IPBM (2011) „Methodology for Formulating and Applying Performance Measures Used in Strategic Planning Documents”, Office of the Prime Minister of Lithuania.

31 United Nations Development Programme and Ministry of Education-PBILD (2013) "Science and technological Development of the Republic of Serbia”, Analysis of the planning process in cities and municipalities in the Republic of Serbia, Zrenjanin.

32 Rabrenović, M.(2011) „Strategic management in public sector”, Official Gazette of the Republic of Serbia, Belgrade. 
The reports should be in standardized format. They are usually made on yearly basis Theyprovide information on the progress and they help in making a decision about further implementation of certain activities. Thus the decision makers and users are enabled to follow the progress of the adopted Development strategy/action plan in a structural way.

The time intervals at which monitoring is carried out depend primarily on the period covered by the adopted strategic document (one-year, two-year, multiyear), but also on the nature and scope of the public policy we follow. Reporting intervals must be consistent with the timeframes for collecting the data necessary to track those results in an agreed format. One important reason for not implementing strategies is the lack of constant monitoring and evaluation in municipalities. Research results give the answer whether the mechanisms for successful monitoring and implementation of adopted strategic policies have been established. In order to avoid that the strategies become just the lists of wishes they have to be conceived in such a way to ensure their efficient and effective implementation. ${ }^{33}$ Based on the research results we can conclude that the monitoring process organization is the main problem in integral strategic documents. The research results are compared by the SCTM analysis. ${ }^{34}$ The first step should be to raise awareness of the importance and needs of systematic continuous monitoring throughout the organization through a set of explicitly defined tools, as a major obstacle is the lack of awareness and insufficient knowledge of the importance of implementing the concept itself. Tracking tools have three basic functions ${ }^{35}$ :

- Monitoring - all data for successful monitoring is collected and integrated into one document.

- Management - provides an overview of the current state of play during the implementation of the strategy, for each of the previous six months, which is a defined policy monitoring interval.

- Results-oriented enables process / implementation monitoring, but does not lose sight of the importance of results, and therefore demonstrates how the activities implemented contribute to the implementation of results.

Through all research components, results suggest that there is insufficient knowledge of the employees in the domain of strategic documents implementation, as the subjects' answers to all questions about their knowledge on established monitoring and evaluation process were either 1 or 2 on the 1-5 scale,

33 Čeliković.Z.(2017) „From good guidelines to good practice:New Model of Corporate Governance in Public Enterprises in Serbia”, Economics Ideas and Practice, Faculty of Economics, Belgrade,pp. 51-68.

34 Standing Conference of Towns and Municipalities -SCTM (2014) „Mapping of municipalities", Belgrade.

35 Directions for Economic Planning (2014) „Tools for strategic planning”, Sarajevo. 
which is alarming information. At the same time the analysis suggests bad results of the public sector. At the same time, the analysis points to poor public sector performance. More than half of the respondents answered that they did not have a monitoring unit in place, in one third of the respondents this function was entrusted to an individual in addition to other work tasks. The most frequent argument against the public sector refers to its 'inefficiency. ${ }^{36}$

The key recommendation stemming from a detailed analysis is the following: There is no one universal model that can enable the monitoring and evaluation models to flourish in practice. The final responsibility for optimal system functioning lies with institution executive. The monitoring and control development is a constant and well documented system conceived to identify weaknesses, established measures for defects elimination, ensure implementation and monitoring of necessary corrective actions, and periodical estimation of internal controls adequacy. It is important to underline that the purpose of reporting is timely system weaknesses and defects detection with the aim of further development of the system, as well as identification of preparation and relevant progress information spreading possibilities - the progress also made in the making of decisions on further steps.

\section{Conclusion}

Strategic management is defined as a goal-oriented, long-term, constant, comprehensive and synergetic process which affects all aspects of life (economic, social, ecological and institutional) on every level. The successful implementation of strategic management depends of state authorities' capability to enable their personnel for public sector management. In reform processes both developing and content programming and planning process harmonization is necessary on the state and local level, as well as clear definition of indicators of success at the national level, and formulation of indicators examples according to the development domains. More detailed analysis of adopted strategic documents implementation suggests that the strategies haven't proved to be efficient in set goals fulfillment aiming at establishment of a competitive economy, poverty reduction, the rule of law, good administration building and reduction of environment pollution. What has been pointed out as the main shortcoming is inadequately established monitoring and evaluation system, as well as the lack of revision of the adopted documents according to the economic situation changes. In Serbia there is no overarching document in the form of national strategic development plan based on a long-term vision with clearly defined priorities,

36 Stamatović, M., Maksimović, S., Tornjanski, A.(2016) „The comparison between public and private sectorefficiency: Are the bureaucratic procedures the source of inefficiency?",Ekonomika, vol. 62, no. 3, pp. 111-122. 
measures and activities for their implementation. There are some strategies with a prefix 'national', but because of their content they cannot be seen as overarching ones as they deal with strategic planning of particular sectors. Bearing in mind that strategic documents are not synchronized, as well as that there is a lack of reporting on the implementation process, it is imperative to establish synchronized mechanisms and methods of monitoring and evaluation of developing and sector strategic documents.

In order to improve the public sector management, it is necessary to clearly define roles, authorizations, responsibilities and duties, at each administrative level, as well as to establish coordinative mechanisms for managing and monitoring reports on programs and projects implementation progress. It is necessary to synchronize the dynamic of the calendar of strategic plans revision vertically and horizontally on all administrative levels, as well as budgetary calendars. Bearing in mind the EU accession aspirations, the integrated strategic planning system also needs to consider requirements and obligations stemming from the accession process.Based on the overall analysis the efficient and functional strategic planning system requires: a precise frame, a standard methodological frame of creation of strategic plans on all levels, synchronized strategic planning and program budgeting, developed monitoring mechanism, developed mechanism of strategic documents implementation monitoring and evaluation, connection of development and public institution priorities, developed institutions with the appropriate organizational, human and financial capacities for management of developing processes on all administrative levels.

In the future, it can be further studied in which way the integrated planning system enables the realization of synergetic effects in fulfillment of defined goals and measures. It would also be interesting to examine which degree of interaction allows monitoring of the realized policies top-down, as well as the way in which these interactions enable comparability and synchronization of strategic documents.

\section{Literature:}

- Andjelic, G., Djaković, V.(2013),Public sector reform of the Republic of Serbia",Business Economy, Vol. 7, $\mathrm{N}_{0} 7$, pp. 59-78.

- Bataljević,D.,Jerotijević,D.,Logarušić,D.(2016) „UporednaanalizaNajpoznati jihmodelalokalnesamouprave”,Ekonomika, Niš, Vol.62., pp.141-154.

- Cvijović, M.(2014),,Strategic planning and management on the local level in Serbia", Chamber ofCommerce and Industry of Serbia.

- Čeliković, Z.(2017) „From good guidelines to good practice:New Model of Corporate Governance in Public Enterprises in Serbia”, Economics Ideas and Practice, Faculty of Economics, Belgrade,pp. 51-68. 
- Directions for Economic Planning (2014),,Tools for strategic planning”, Sarajevo.

- Efimov,Lj.,Trpeski,P.,Gockov,G.(2016) „A comparative analysis of the most popular models of local government”,Ekonomika, Niš, vol. 62. pp.29-48.

- European Commission (2006),Common Indicators for Monitoring Rural Development Programming 2000-2006“,Commission working document d/761 Final,Brussels.

- European Commission (2006),Indicators for Monitoring and Evaluation: An indicative methodology", The New Programmimg period 2000-2006, Working Paper 3, Brussels.

- Improvement of Performance-Based Management-IPBM (2011) „Methodology for Formulating and Applying Performance Measures Used in Strategic Planning Documents", Office of the Prime Minister of Lithuania.

- Hilb,M.(2008) „New Corporate Governance:from good guidelines to great practice",Corporate Governance:An International Review, vol.13,pp.569-589.

- Hinna A., Scarozza, D., Rotundi, F. (2018) „Implementing risk management in the Italian publicsector:Hybridization between old and new practices", International Journal of Public Administration,41(2),pp. 110-128.

- Jang, O.,Kvin. L. (2003) „Writing Effective Practical Policy Proposals: A Guide for Practical Adviser politics in Centraland Eastern European countries", Open Society Institute, Belgrade.

- John, P.(2002) „Quantitative research in Theory an Methods in Political Science", DejvidMarš, Geri Stoker, Palgrave, New York, USA.

- Krivins,M.(2014) „Ideas for operationalizing the monitoring, reporting and evaluation (MRE) systems in the Reform Strategy Public Administration (PAR) and the Action Plan for its Implementation in the Republic of Serbia", SIGMA, Belgrade.

- Kusek,J. Rist,R.(2004) „A Handbook for Development Practitioners:Ten Steps to a Results-Based Monitoring and Evaluation System", The World Bank, Washington.

- Maksimović, S. (2016),,Relatonship between strategic planning and program budgeting in the function of efficientmanagement of public policies, "Doctoral dissertation, „Union- Nikola Tesla” University, Faculty of Business and Industrial Management, Belgrade.

- Maksimović, S., Lunjić, A., Parojčić, D.(2020)„Financial management and control - A New Management Concept in the Context of the Serbian Public Sector", Megatrend revija, Vol.18. No.2.

- Maksimović, S., Stamatović, M. (2018) „Risk management as a part of management public investment projects", $4^{\text {th }}$ - International Scientific Conference International Scientific Conference- Innovation as an initiator of the development,Faculty of Applied Management, Economics and Finance, Belgrade, pp.4-9. 
- Ministry of Finance of the Republic of Serbia (2019),,The manual for financial management and control", Belgrade.

- Municipal Improvement and Revival Programme MIR2 (2008),Strategic planning and implementation, $2^{\text {nd }}$ phase,Jablanica and Pcinja District”, Leskovac.

- Official Gazette of the Republic of Serbia, The Law on the Budget System [Serbian version], no. 54/2009,73/2010,101/2011,93/2012,62/2013,63/2013,1 08/2013, 142/2014, 68/2015, 103/2015, 99/2016, 113/2017, 95/2018, 31/2019 i 72/2019, 149/2020).

- Official Gazette of the Republic of Serbia, The Law of Local Self-Governments Financing, [Serbian version] 62/2006; 47/2011; 93/2012; 99/2013; 125/2014; 95/2015, 83/2016, 104/2016/96/201, 95/2018 and 86/2019, Belgrade, 2006-2019.

- Official Gazette of the Republic of Serbia, The Law of Ministries, no. 44/2014, Belgrade, 2014, 14/2015,

- 54/2015, 96/2015, 62/2017.

- Official Gazette of the Republic of Serbia, The Law of State Government, no. 79/2005, 101/2007, 47/2018, 30/2018.

- Official Gazette of the Republic of Serbia, The Law of Regional Development, no. 51/2009, 30/2010, 89/2015.

- Pavlović-Križanić, T.(2010)„Handbook of Strategic Planning and Local Development Management",Center for Regionalism and Friedrich Ebert Stiftung, pp. 30-36, 2010.

- Parashkevova, E. (2020),Integrating Project Risk into Risk Management Strategies in Public

- SectorOrganizations",International E-Journal of Advances in Social Sciences 6 (16), pp. 283-293.

- Rabrenović, M.(2011),Strategic management in public sector” [Serbian version], Official Gazette of the Republic of Serbia, Belgrade.

- Serbia - Local Government Reform Program -SLGRP(2002)"Model of strategic plan of municipality", Belgrade.

- Stamatović, M., Maksimović, S., Sućeska, A.(2020) „Risk Management as a part of the Internal System of financial controls-practice in the public sector of Serbia",PanevropskiuniverzitetApeiron, Fakultetposlovneekonomije, Economy and Market Communication Review - EMC Review",VolX, No 2.

- Stamatović, M., Maksimović, S. and Tornjanski, A.(2016)'The comparison between public and private sector efficiency: Are the bureaucratic procedures the source of inefficiency?'Ekonomika,Niš,Vol. 62, no. 3, pp. 111-122.

- Standing Conference of Towns and Municipalities-SCTM (2015),Analysis of strategic planning and program budgeting on the level of local selfgovernments", Belgrade.

- Standing Conference of Towns and Municipalities-SCTM (2014) „Mapping of municipalities", Belgrade. 
- Standing Conference of Towns and Municipalities-SCTM (2012),Monitoring and evaluation of strategies of localsustainable development", Belgrade.

- United Nations Development Programme and Ministry of Education-PBILD (2013) „Analysis of the planning process in cities and municipalities in the Republic of Serbia",Science and technological Development of the Republic of Serbia,Zrenjanin.

- United States Agency for International Development-USAID (2008),,The Guide of strategic planning for towns and municipalities", Belgrade.

- Žarković-Rakić, J., Aleksić-Mirić, A., Marić S., Miletić. J., Lazarević. M. (2012) „Handbook for Monitoring and Evaluation of Public Administration Reform Policy", Foundation for the Development of Economic Science, Belgrade. 


\section{PRAĆENJE I EVALUACIJA USVOJENIH STRATEŠKIH DOKUMENATA U SRBIJI}

Apstrakt: Cilj rada je usmeren na analizu procesa primene strategijskog planiranja $u$ Srbiji, koje podrazumeva proces kreiranja razvojnih ciljeva, prioriteta i definisanje načina njihovog ostvarenja. Radi ostvarenja definisanih ciljeva, strategije imaju akcione planove za njihovo sprovođenje, odnosno godišnje ili višegodišnje planove, kojima se detaljnije definišu aktivnosti, mere i projekti, nosioci aktivnosti, rokovi za sprovođenje, indikatori uspešnosti, finansijska sredstva, izvori finansiranja, zakonodavni i institucionalni okvir. Predmet istraživanja ovog rada predstavlja identifikacija postojećeg stanja u pogledu sprovođenja aktuelnih strateških dokumenata, definisanje problema i nedostataka procesa monitoringa i izveštavanja o stepenu evaluacije onoga što je postignuto. $\mathrm{Na}$ osnovu zaključaka o potencijalima i problemima date su preporuke za transparentnije $i$ efikasnije upravljanje, čime bi se stvorili uslovi za pravilno usmeravanje budžetskih $i$ vanbudžetskih sredstava, što bi stvorilo pretpostavke za brži socio-ekonomski razvoj i za uspešno funkcionisanje bez obzira na promene u okruženju.

Ključne reči: strategijsko planiranje, strateško upravljanje, javne politike, efikasno upravljanje. 